Received 19.03.2017 Reviewed 22.06.2017 Accepted 20.09.2017

A - study design

B - data collection

C - statistical analysis

D - data interpretation

$\mathbf{E}$ - manuscript preparation

F - literature search

\section{The comparison study for the models of reservoir release rule for irrigation. Case study: Sutami Reservoir}

\author{
Widandi SOETOPO $^{\text {ABCDEF }}{ }^{凶}$, SUHARDJONO $^{\mathrm{BE}}$, \\ USSY ANDAWAYANTI $^{\text {BE }}$, Rini Wahyu SAYEKTI ${ }^{\text {BE }}$, Janu ISMOYO ${ }^{\text {BE }}$
}

Brawijaya University, Faculty of Engineering, Jl. M.T. Haryono 167 Malang 65145 Jawa Timur, Indonesia; e-mail:widandi@ub.ac.id, suhardjono@ub.ac.id, uandawayanti@ub.ac.id, rinyekti@gmail.com,mjanu@ub.ac.id

For citation: Soetopo W., Suhardjono, Andawayanti U., Sayekti R.W., Ismoyo J. 2018. The comparison study for the models of reservoir release rule for irrigation. Case study: Sutami Reservoir. Journal of Water and Land Development. No. 36 p. 153-160. DOI: 10.2478/jwld-2018-0015.

\begin{abstract}
Three models of release rule for operating a large reservoir for irrigation water supply are discussed in this paper. The models are a 50-grid storage continuous line restricted release rule, a single rule curve release rule, and a multi 4 rule curves release rule. These three models are to be optimized by stochastic simulation using 30 year inflow data with the maximization of the average monetary annual production in the irrigation area as the objective function. The purpose of this study is to look for the proper release rule for operating the Sutami Reservoir. The optimization is done first by the random search stochastic simulation model to generate a number of alternative solutions. Using these solutions as a generation of solutions, the genetic algorithm model is the applied to improve the solution. Afterward the best of solutions are checked by the Add-Ins Solver of MS-Excel 2010 to see if they can still be improved further. The results show that the 4 rule curves model gives the best solution with the average monetary annual production in the irrigation area of USD 72.248 million.
\end{abstract}

Key words: release, reservoir, rule, simulation, stochastic

\section{INTRODUCTION}

In general, reservoirs of various storage capacity are highly valuable. Even small reservoirs with capacity under $100,000 \mathrm{~m}^{3}$ have considerable economic, hydrologic, and environmental significance [MIODUSZEWSKI 2012]. To realize their worth, reservoirs must be operated properly. There are three models of reservoir operation being considered in this paper, all of which have the storage state (in percentage of active storage) at the beginning of operating period as the input variable. The output variable of the three models is the reservoir release of the operating period (in percentage of the water demand of the corresponding period). The first reservoir operation model is a 50-grid storage continuous line restricted release rule, where the continuous line covers the entire range of the active storage for determining the reservoir release [MCMAHON, MEIN 1978].

A single multipurpose irrigation reservoir can have an annual cycle of operation with a fixed starting point of refilling [SOJKA et al. 2016]. The second reservoir operation model is an annual cycle of the single rule curve based release rule, where the points of rule curve define the lower bound of storage states in the active storage (the upper bound is the top of active storage capacity). In this case the rule curve is target storage levels [WURB 1996]. The third reservoir operation model is the variant of the single rule curve based release rule by using four curves instead of just one curve. In this multi 4 rule curves based release rule, the curves are stacked from the top curve (with the highest priority) to the bottom curve (with the lowest priority). This multiple rule curves model is 
much like the conventional rule curves coupled with hedging rules [HUANG et al. 2016; TAGHIAN et al. 2014; WAN et al. 2016].

Obviously, the complicated nature of these reservoir operation models cannot be optimized by using the standard method of optimization like the linear programming or the dynamic programming. On the other hand, stochastic simulation models have capability for optimizing such complicated optimization problems. Definitely, these stochastic simulation models can achieve only near optimal solutions, but they can easily be adjusted to suit complicated optimization problems. Basically all stochastic simulation optimization models are generating a random sample of alternative solutions and then picking the best solution from the sample. In fact, simulation-optimization models can be used for quantitative allocation of surface water resources [WOJAS, TYSZEWSKI 2013]. The two models of Stochastic Simulation for optimization to be used in this case of study are the random search, and the genetic algorithm (GA). The MS-Excel Solver of Evolutionary (solving method) is also belong to the Stochastic Simulation model and is used in this study to check the best of solutions to see if they can still be improved further. The genetic algorithm, which can be termed as a metaheuristic algorithm, has been combined with other algorithms for searching best solutions of a groundwater scheme [KUMAR et al. 2015].

\section{MATERIALS AND METHODS}

\section{STUDY OBJECT}

In this case of study, the reservoir is the Sutami Reservoir which is located in the Brantas River Basin in the province of East Java. The reservoir has an active storage capacity of 161.1 million $\mathrm{m}^{3}$. The Sutami Reservoir is slated to supply irrigation water for an area of 76898 ha in three cropping season annually. It has also been obliged to supply the municipal water all along the year, to generate hydropower, and to provide storage for flood control. The Sutami Reservoir is being supplied with the inflow from the release of the Sengguruh Reservoir, which is located at the confluence of the Brantas River and the Lesti River. In addition, there is also the inflow from the Metro River. The Sutami Reservoir is operated in 10-days period (with a total of 36 periods in a year). The location of the Sutami Reservoir can be seen in the Figure 1 .

The purpose of this study is to look for the proper release rule for operating a large reservoir such as the Sutami. The goal of this study is to obtain an optimal model of release rule for operating the Sutami Reservoir with the main purpose of irrigation. Therefore the scope of the research is the optimization of the release rule of the Sutami Reservoir operation model. Three alternatives of reservoir operation model to be optimized is (1) a 50-grid storage continuous line restricted release rule, (2) the single rule curve based release

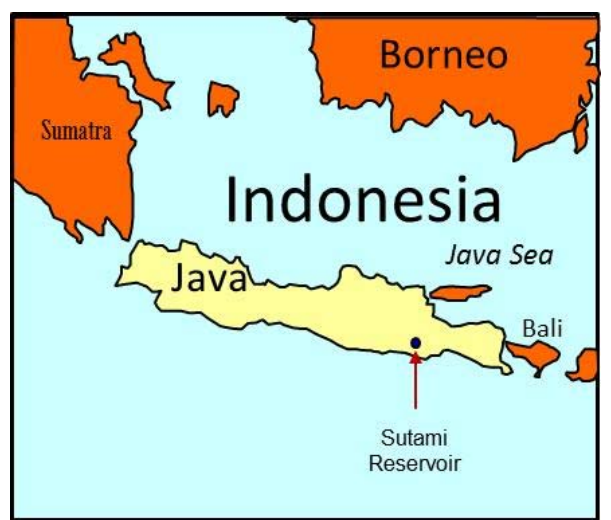

Fig. 1. The location of study; source: own elaboration

rule, and (3) the multiple 4 rule curves based release rule. Two stochastic simulation models to be used for optimizing these three alternatives of reservoir operation model are (1) the random search, and (2) the genetic algorithm.

\section{THE RELEASE RULE FOR RESERVOIR OPERATION}

All three reservoir operation model being discussed in this article is based on keeping the balance of the water availability and the water demand all the time. The balancing of these two components of reservoir operation is accomplished by manipulating the available storage. For the storage based release rule, the release line will lower the level of fulfillment as the water storage become lower. For the single rule curve based release rule, the rule curve will act as the time zone partition for the level of fulfillment. For the multiple rule curves based release rule, beside the time zone partition, there is also storage space partition.

The first reservoir operation model being investigated in this study is the storage based release rule. In this model, the reservoir release of a period (expressed in the percentage of the water demand) is determined by inputting the state of storage (in percentage of active storage) at the beginning of the period, into the chart of storage based release rule in Figure 2.

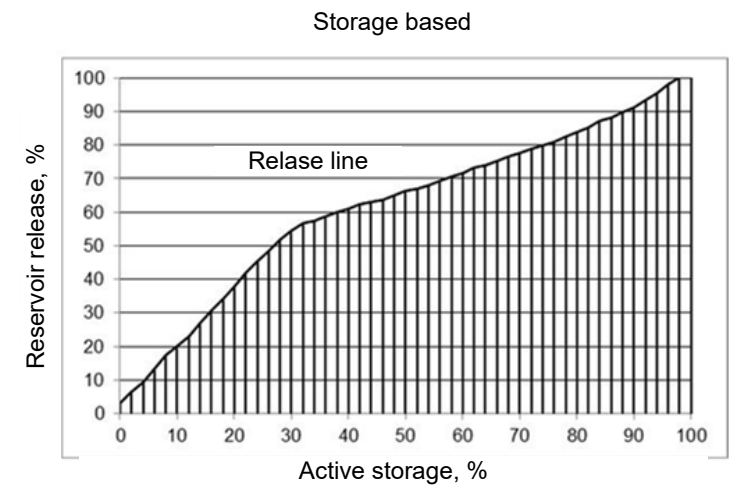

Fig. 2. The storage based release rule with 50 grid of storage, in the optimal state; source: own elaboration 
The state of storage is entering the chart at the horizontal axis, hit the release line, and end up at the vertical axis to determine the reservoir release of the period. In this case of study, the release line is a broken continuous line formed by the 50 uniform grids of active storage (each grid is $2 \%$ wide). The height of points in the release line are the parameters to be optimized by the stochastic simulation models.

The second reservoir operation model is the single rule curve based release rule, where the points of rule curve define the lower bound of storage states in the active storage (the upper bound is the top of active storage capacity. In the stochastic simulation procedure, the state of storage is forbidden to go below the lower bound, and if necessary the release should be reduced (below the demand) in order to comply with this rule. A single rule curve can be depicted in Figure 3.

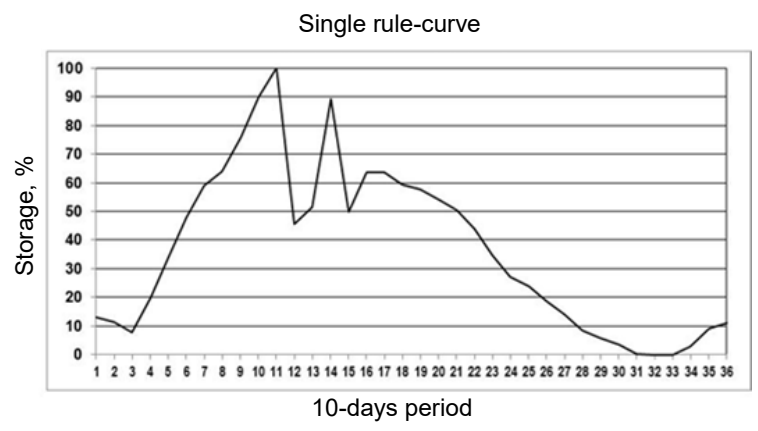

Fig. 3. The single rule curve based release rule for a year, in the optimal state; source: own elaboration

A point in the rule curve can be defined as a target of storage state at the end of a period (in percent of the active storage of reservoir). The height of points in the curve are the parameters to be optimized by the stochastic simulation models.

The third reservoir operation model is the multiple rule curves based release rule, where 3 more curves are being added below the main (original) curve. These additional curves can be regarded as the improvement of the single curve model as they can give more gradual reduction in fulfillment. This multi 4 rule curves based release rule can be depicted in Figure 4.

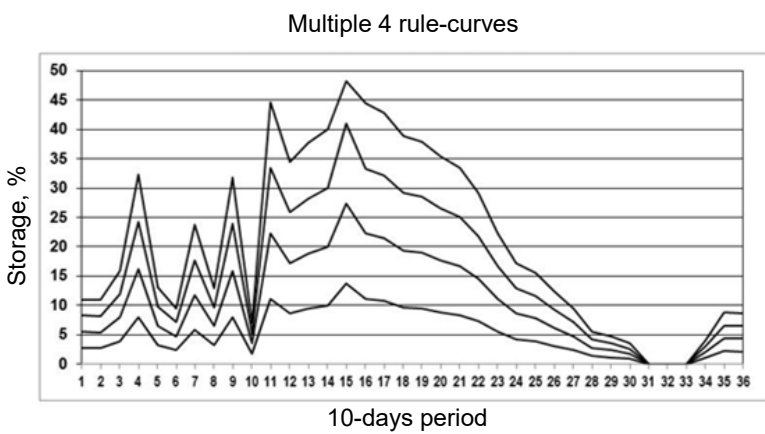

Fig. 4. The multi rule curves based release rule for a year, in the optimal state; source: own elaboration
The main curve has the original demand of water as the target for fulfilling. The next curve below it has a percentage of the original demand of water as the target for fulfilling, and the next lower curve has a lower percentage for fulfillment, and so on. In this case of study, these targets of fulfillment are predetermined. The height of the lower curves are also predetermined as a fixed percentages of the main (top) curve. These predetermined values are presented in the Table 1.

Table 1. The targets of fulfillment of multiple rule curves

\begin{tabular}{|c|c|c|}
\hline \multirow{2}{*}{$\begin{array}{c}\text { Curve } \\
\text { No. }\end{array}$} & Height of curves & Target of fulfillment \\
\cline { 2 - 3 } & \multicolumn{2}{|c|}{$\%$} \\
\hline 1 & 100 & 100 \\
\hline 2 & 75 & 90 \\
\hline 3 & 50 & 80 \\
\hline 4 & 25 & 70 \\
\hline
\end{tabular}

Source: own elaboration.

If the state of storage at the beginning of a period is above curve 1 then the target of fulfillment at that period is $100 \%$ (of the original demand), if it is above curve 2 then the target of fulfillment is $90 \%$, and so on. The height of points in the main (top) curve are the parameters to be optimized by the stochastic simulation models.

\section{THE SINE-PRODUCT MODEL}

The objective function of the optimization model for the Sutami Reservoir operation is to maximize the average monetary annual production in the irrigation area. The production in the irrigation area is basically the crop yield. The relationship between the applied water (irrigation water delivery) and the crop yield production as presented by ENGLISH et al. [2002] can be depicted in the Figure 5.

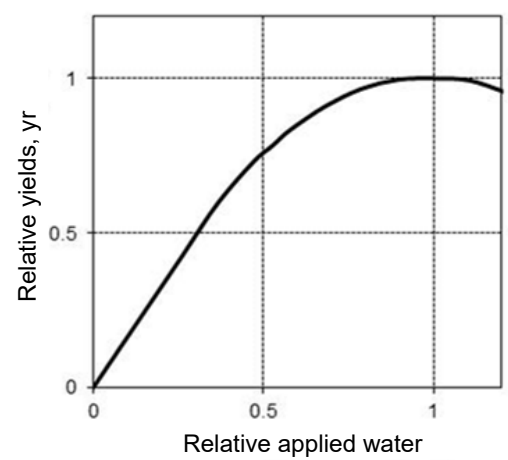

Fig. 5. Relationship between applied water and crop yield; source: ENGLISH et al. [2002]

The production curve in Figure 4 is the relationship between the amount of relative applied irrigation water (in percentage of full supply) to the amount of relative crop yield (in percentage of maximum yield). The mathematical form of the production curve is proposed in previous studies [SOETOPO 2007; 2009]. 
In order to fit the production curve in Figure 4, an approach has been made to use a model with sine functions for each period of water application as shown Equation (1).

$$
\begin{gathered}
Y r_{i}=\left[\operatorname { s i n } \left\{\left(\left[A W r_{i}-a \sin \left(A W r_{i} \cdot 2 \pi\right)\right] \cdot\right.\right.\right. \\
\left.\left.\left.\left[1-b \sin \left(A W r_{i} \cdot \pi\right)\right]^{\mathrm{c}}\right)^{\mathrm{d}} \pi / 2\right\}\right]^{\mathrm{e}}
\end{gathered}
$$

Where: $Y r_{i}=$ the representation of $Y_{r}$ (crop production/yield) at each period/stage; $A W r_{i}=$ the applied water at the corresponding period/stage.

For the number of period/stage in a cropping season of 12 (in this case of study), values of the calibrated parameters of $a, b, c, d$, and $e$ are presented in the Table 2 .

Table 2. The calibrated parameters of the sine function

\begin{tabular}{|c|c|}
\hline Parameter & Calibrated value \\
\hline$a$ & 0.12824 \\
\hline$b$ & 0.31559 \\
\hline$c$ & 1.67754 \\
\hline$d$ & 0.12412 \\
\hline$e$ & 1.20000 \\
\hline
\end{tabular}

Source: own study.

Meanwhile the crop production function for a cropping season is described as Equation (2).

$$
Y r=Y r_{1} \cdot Y r_{2} \cdot Y r_{3} \cdot \ldots \cdot Y r_{n}
$$

Where: $n=$ the number of period/stage in the cropping season ( $=12$ periods).

The $A W r_{i}, Y r_{i}$, and $Y r$ are all the relative values (between 0 and 1). $A W r_{i}$ are relative to the standard water requirement which will give the maximum $\mathrm{Yr}$, whereas $\mathrm{Yr}$ is relative to the potentially maximum $\mathrm{Yr}$. The Equations (1) and (2) constitute the sine-product model [SOETOPO 2007; 2009], being used for estimating the crop production in the irrigation area (in percent of maximum production).

\section{THE STOCHASTIC SIMULATION}

In a simulation of reservoir operation, a procedure is composed and run in computer to simulate the real time reservoir operation. In the stochastic simulation of reservoir operation, random input can be applied in the parameters of reservoir operation to produce stochastic output. In this study, the output is the crop yield. A multiple runs of stochastic simulation of reservoir operation will produce a stochastic sample of crop yield. The maximum value of this sample represents the provisional best solution. In general, the larger number of run will give a larger sample of stochastic solutions, and therefore will produce a higher maximum value of output (crop yield).

There are three stochastic simulation models being employed for optimization in this study. In the first phase of optimization, each model of reservoir operation is optimized by the random search (stochastic simulation model). In the second phase of optimi- zation, the genetic algorithm (stochastic simulation model) is applied to see if it can make improvement on the results of the first phase. In the third and last phase of optimization, the best results are checked by the Add-Ins Solver of MS-Excel 2010 (stochastic simulation model) to see if there is still any further improvement.

\section{THE INPUT OF STOCHASTIC SIMULATION}

The stochastic simulation for the operation of the Sutami Reservoir is set on the MS-Excel 2010 program. The input data can be summarized in the Table 3 .

Table 3. The input data of stochastic simulation model for the reservoir operation.

\begin{tabular}{|c|l|}
\hline No. & \multicolumn{1}{|c|}{ Data item } \\
\hline 1 & the reservoir inflow discharge for 30 years (10-days period) \\
\hline 2 & the yearly water requirement (10-days period) \\
\hline 3 & the reservoir evaporation \\
\hline 4 & the capacity of the reservoir active storage \\
\hline 5 & the capacity of the reservoir dead storage \\
\hline 6 & the curve of reservoir surface area \\
\hline 7 & the total area of irrigation \\
\hline 8 & $\begin{array}{l}\text { the monetary value of the production of a unit area } \\
\text { of irrigation }\end{array}$ \\
\hline
\end{tabular}

Source: own elaboration.

\section{THE STRUCTURE OF RANDOM SEARCH}

The stochastic simulation model of random search is done on each of the three models of reservoir operation to generate 16 solutions respectively. The random search procedure is consist of 2 stages, the initial stage and the improvement stage. In the initial stage, the reservoir operation is simulated for a number of iteration, and the best generated solution is accepted as the current best solution. In the improvement stage, the best current solution is used as the center of search within a search range. If a better solution is found, then it will become the current best solution. After a certain number of iteration, then the search range is changed with a narrower one. The parameters of the random search procedure are presented in Table 4.

Table 4. The parameters of the random search procedure

\begin{tabular}{|l|c|c|c|}
\hline \multicolumn{1}{|c|}{ Stage } & Parameter & $\begin{array}{c}\text { Storage } \\
\text { based }\end{array}$ & $\begin{array}{c}\text { Rule curve } \\
\text { based }\end{array}$ \\
\hline Initial & iteration & 5000 & 5000 \\
\hline \multirow{2}{*}{ Improvement } & iteration & 2000 & 1000 \\
\cline { 2 - 4 } & number of search ranges & 14 & 36 \\
\hline
\end{tabular}

Source: own elaboration.

\section{THE STRUCTURE OF GENETIC ALGORITHM}

The genetic algorithm (GA) procedure is the continuation of the random search procedure. After 16 solutions have been generated for each of the three models of reservoir operation (by using the random search procedure), the stochastic simulation model of 
genetic algorithm is applied, using those generated solutions as the initial generation of solutions. These 16 solutions are developed into 120 new solutions by applying the crossover on every combination of 2 solutions among the generation. These generated 120 solutions are established as the population. The next is to apply the reproduction by selecting the top 16 solutions from the current population to make the next generation of solutions, and the process begin again with crossover, and so on. The parameters of the genetic algorithm procedure are presented in Table 5 .

Table 5. The parameters of the genetic algorithm procedure

\begin{tabular}{|l|r|}
\hline Parameter & Value \\
\hline Generation size & 16 \\
\hline Population size & 120 \\
\hline Iteration of crossover & 1000 \\
\hline
\end{tabular}

Source: own elaboration.

In the crossover, each possible combination of a pair of solutions is stochastically crossed. In this is stochastically crossing procedure, a randomly portion of each parameter of a solution in the pair is combined with a randomly portion of its matching parameter in the other solution of the pair. The combined all parameters will establish a new solution. The stochastically generated solutions will form a new population (of 120 new solutions). The value of randomly portion (of a parameter) is generated by the computer (MSExcel 2010).

After the a number iteration of crossover-reproduction process, the population become complete homogeneous, and further improvement by crossover is impossible because every possible pair of solutions are identical and will produce exactly the same identical solution. If this condition has been reached, then the genetic algorithm procedure is then stopped.

\section{THE SOLVER}

The Add-Ins Solver of MS-Excel 2010 program package provides the three options of applied programs, one of them is the evolutionary solving method (ESM). The ESM is basically a genetic algorithm model, and therefore it is a stochastic simulation model. It came in ready use package and there is not any information available about the structure of its optimization parameters. The using of the ESM program is by defining the ranges (in the Excel worksheet) of the objective function (crop yield), the decision variables (parameters of the reservoir operation model), and constraints (including the reservoir water balance). Then the ESM program is run again and again until there is no more improvement. The role of the ESM program in this study is to check the best of solutions of the three reservoir operation models whether they can still be improved further.

\section{THE OPTIMIZATION FOR SETTING UP RELEASE LINE AND RULE CURVES}

The release line in the storage based release rule and the rule curves in the rule curve based release rules (single curve and multi 4 curves) are the parameters to be set up by the optimization using stochastic simulation models (the random search and the genetic algorithm). By using the optimization, these parameters of release line and rule curves are to be set up at their optimal values so as to maximize the objective function of crop yield. Using the input data of stochastic simulation (Tab. 3) and the random number from the computer, the optimization is conducted firstly by the random search to produce 16 solutions for each of the three reservoir operation models. The best of 16 solutions (with the highest crop yield) represents the optimal solution for each reservoir operation model.

Next the genetic algorithm is applied on each of reservoir operation model. The 16 solutions of the Random Search are used as the initial generation of solutions. The iterated crossover-reproduction process will make the generation of solutions more homogeneous and at the same time it may improve the solution (with the higher crop yield). The final result of solution is achieved when the generation of solutions is completely homogeneous.

Finally, the evolutionary solving method (ESM) in the Add-Ins Solver of MS-Excel 2010 program package is applied to check if the optimal results of the genetic algorithm can still be improved further. For each of the three reservoir operation models, the ESM is run over and over again until there is no more improvement if there is any. And this is the final results of the optimization for the three reservoir operation models.

\section{RESULTS AND DISCUSSION}

The results of running of the stochastic simulations for optimizing the three reservoir operation models and the corresponding checking by evolutionary solver procedure in Add-Ins Solver package of the MS-Excel are depicted in the Figure 2 (for the storage based release rule), the Figure 3 (for the single rule curve based release rule), and the Figure 4 (for the multiple rule curve based release rule). These line release line and rule curves are the optimal parameters for each of the three reservoir operation models.

The measure of a reservoir operation model is its value of the objective function. The optimization by random search has produced 16 objective function values for each reservoir operation model, and the best of the 16 values represent the optimal solution. The application of the genetic algorithm is an effort to seek better solutions than those produced by the random search. And the application of the Solver is a further check for searching better solution. The values of the objective function (maximum crop yield) are presented in the Table 6. 
Table 6. The values of objective function (million USD)

\begin{tabular}{|c|c|c|c|}
\hline \multirow{2}{*}{$\begin{array}{l}\text { Number } \\
\text { of } \\
\text { running }\end{array}$} & \multirow{2}{*}{$\begin{array}{l}50 \text { grid storage } \\
\text { continues line } \\
\text { restricted release rule }\end{array}$} & \multicolumn{2}{|c|}{$\begin{array}{l}\text { Rule curve based } \\
\text { release rule }\end{array}$} \\
\hline & & $\begin{array}{l}\text { single } \\
1 \text { curve }\end{array}$ & $\begin{array}{c}\text { multi } \\
4 \text { curve }\end{array}$ \\
\hline 1 & 63.839 & 66.995 & 68.378 \\
\hline 2 & 63.756 & 68.539 & 68.198 \\
\hline 3 & 63.793 & 66.922 & 65.123 \\
\hline 4 & 63.796 & 67.461 & 72.248 \\
\hline 5 & 63.763 & 69.675 & 65.859 \\
\hline 6 & 63.745 & 64.854 & 70.617 \\
\hline 7 & 63.808 & 64.050 & 63.408 \\
\hline 8 & 63.749 & 69.735 & 68.340 \\
\hline 9 & 63.869 & 68.885 & 64.941 \\
\hline 10 & 63.826 & 70.141 & 65.148 \\
\hline 11 & 63.847 & 62.466 & 64.208 \\
\hline 12 & 63.886 & 65.156 & 71.434 \\
\hline 13 & 63.865 & 67.501 & 67.577 \\
\hline 14 & 64.032 & 69.108 & 66.109 \\
\hline 15 & 63.789 & 67.529 & 68.729 \\
\hline 16 & 63.758 & 71.299 & 67.488 \\
\hline Best & 64.032 & 71.299 & 72.248 \\
\hline $\begin{array}{c}\text { Genetic } \\
\text { algorithm }\end{array}$ & 64.396 & - & - \\
\hline Solver & - & - & - \\
\hline
\end{tabular}

Source: own study.

The values of the objective function are representing the average of production in the area of irrigation in 90 cropping seasons (30 years). These values have been maximized by the stochastic simulation models. About the running of the stochastic simulation models for optimization and the performance of the three reservoir operation models, there are some points to be accounted in the follow.

For the storage based release rule, the random search has given the best result of 64.032 million USD, and the genetic algorithm can improve it to 64.396 million USD, whereas the Solver has given no further improvement. For the single rule curve based release rule, the random search has given the best result of 71.299 million USD, and both the genetic algorithm and the Solver has given no further improvement. For the 4 rule curves based release rule, the random search has given the best result of 72.248 million USD, and both the genetic algorithm and the Solver has given no further improvement.

The rule curve based release rules (single curve and multi 4 curves) are significantly better than the storage based release rule. In fact, the Sutami Reservoir has been operated using rule curve models in all these times. The multi 4 rule curves based release rule is somewhat better than single rule curve based release rule. It is undoubtedly because the additional curves have given flexibility in dealing with the difficult inflow-demand situations.

It can be seen that in the optimal states (Fig. 4), there are significant differences in the shapes of the single curve and the multi 4 curves especially in the span of periods $1-14$, which is the reflection of how can different is each model in handling the same inflow-demand situations for the length of 90 cropping seasons (30 years). It can be said that the reservoir operation with a single curve tend to be highly conserved (up to $100 \%$ of the active storage - see Figure 3) as compared to the reservoir operation with multi 4 curves (under $50 \%$ of the active storage - see Figure 4). The single curve is appear to be smooth in the span of periods 3-11, but it actually not always like that in the other alternatives of solution, which have more jagged curve.

The sine-product model has been used in this study for estimating the value of production in the irrigation area in percent of the maximum production. By multiplying the percentage production to the monetary value of the maximum crop production, the objective function is obtained. The use of sine-product model is producing more realistic values of the objective function as different sequences of irrigation water supply through this function will produce different level of crop production in the same irrigation area. Therefore, the optimization of the reservoir operation model in this study is not just simply by maximizing the irrigation area with the assumption of the same crop production level per area under the full water supply.

The use of random search for studying reservoir operation is quite common [J et al. 2015; KANG, PARK 2014; SEIFOLLAHI-AghMiUNi et al. 2016]. In fact the random search is a practical mean for analyzing the reservoir operation while can also give reliable results. The use of genetic algorithm for studying reservoir operation is also quite common [AMIRKHANI et al. 2016; ElABS, EL-GHANDOUR 2014; NAJL et al. 2016]. Altough the genetic algorithm is more complicated than the random search, it is usually provide better results. In fact, the genetic algorithm can be regarded as the development of the random search.

\section{CONCLUSIONS}

1. The rule curve based release rule is the recommended proper release rule for large reservoirs like the Sutami Reservoir. Especially the multiple 4 rule curves which can handle the dry spells better than the single rule curve.

2. The addition of more curves can make the rule curve based release rule to perform even better, although the operational procedure will undoubtedly be more complicated. For the practical application, suitable tables of reservoir releases can be fashioned.

3. The performance of the storage based release rule is below the rule curve based release rule. This can be understandable as the storage based release rule is basically intended for small metropolitan reservoirs.

4. The rule curve based release rule simulation models have structures which is too complex to be optimized by the Solver. Therefore they must be solved by the specially made program for this purpose. 


\section{RECOMMENDATIONS}

1. Further studies can be done about the multiple rule curve especially for the Sutami Reservoir operating rule.

2. The sine-product model can be used in a feasibility study on the expansion of irrigation area of the Sutami Reservoir or other irrigation supplying reservoirs.

3. The sine-product model has the possibility to be applied in designing water management for irrigation schemes.

\section{Acknowledgments}

The authors are expressing their gratitude to all parties who have contribution in completing this article, and have supported the corresponding research.

\section{REFERENCES}

AmirkHANi M., BORZOG-HADDAD O., FALLAH-MEH-DIPOUR E., LOAICIGA H.A. 2016. Multiobjective reservoir operation for water quality optimization. Journal of Irrigation and Drainage Engineering. Vol. 142. Iss. 12 [04016065] p. 1-7.

ElaBS S., El-GHANDOUR H.A. 2014. Multiobjective optimization of Bigge Reservoir operation in dry seasons. Journal of Hydrologic Engineering. Vol. 19. Iss. 9 [05014008] p. 1-7.

ENGLish M.J., SOlOMON K.H., Hoffman G.J. 2002. A paradigm shift in irrigation management. Journal of Irrigation and Drainage Engineering. Vol. 128. Iss. 5 p. 267-277.

Huang C., Zhao J., Wang Z., Shang W. 2016. Optimal hedging rules for two-objective reservoir operation: balancing water supply and environmental flow. Journal of Water Resources Planning and Management. Vol. 142. Iss. 12 [04016053] p. 1-10.

Ji C., JiAng Z., Sun P., ZhANG Y., WANG L. 2015. Research and application of multidimensional dynamic programming in cascade reservoirs based on multilayer nested structure. Journal of Water Resources Planning and Management. Vol. 141. Iss. 7 [04014090] p. 1-13.

KANG M.G., PARK S.W. 2014. Combined simulation-optimization model for assessing irrigation water supply capacities of reservoirs. Journal of Irrigation and Drainage Engineering. Vol. 140. Iss. 5 [04014005] p. $1-11$.

Kumar D., Ch S., Mathur S., AdAmowsKi J. 2015. Multiobjective optimization of in-situ bioremediation of groundwater using a hybrid metaheuristic technique based on differential evolution, genetic algorithms and simulated annealing. Journal Water and Land Development. No. 27 p. 29-40. DOI 10.1515/jwld-2015-0022.

McMahon T.A., MeIn R.G. 1978. Reservoir capacity and yield. Amsterdam. Elsevier Scientific Publishing Company. ISBN 9780080870007 pp. 212.

MiodUSZEWSKI W. 2012. Small water reservoirs - their function and construction. Journal Water and Land Development. No. 17 p. 45-52.

NaJl A.A., Haghighi A., SAMANI H.M.V. 2016. Simultaneous optimization of operating rules and rule curves for multireservoir systems using a self-adaptive simulation GA model. Journal of Water Resources Planning and Management. Vol. 142. Iss. 10 [04016041] p. 1-12.

Seifollahi-Aghmiuni S., Borzog-Haddad O., LOAiciga H.A. 2016. Development of a sample multiattribute and multireservoir system for testing operational models. Journal of Irrigation and Drainage Engineering. Vol. 142. Iss. 1 [04015039] p. 1-16.

Soetopo W. 2007. Penerapan model Sinus-Perkalian pada rumusan fungsi kinerja irigasi untuk optimasi dengan program dinamik [Application of sine-product model as the irrigation production function for optimization with dynamic programming]. Jurnal Teknik - Fakultas Teknik Universitas Brawijaya. Vol. 14. Iss. 2 p. 97-103.

SoETOPO W. 2009. Application of sine-product model for operation of irrigation reservoir. World Applied Sciences Journal. Vol. 7. Iss. 8 p. 1060-1064.

SOJKA M., JASKUŁA J., WICHER-DYSARZ J., DYSARZ T. 2016. Assessment of dam construction impact on hydrological regime changes in lowland river - A case of study: The Stare Miasto reservoir located on the Powa River. Journal Water and Land Development. No. 30 p. 119-125. DOI 10.1515/jwld-2016-0028.

Taghian M., Rosbjerg D., Haghighi A., Madsen H. 2014. Optimization of conventional rule curves coupled with hedging rules for reservoir operation. Journal of Water Resources Planning and Management. Vol. 140. Iss. 5 p. 693-698.

Wan W., Zhao J., Lund J.R., Zhao T., Lei X., Wang H. 2016. Optimal hedging rule for reservoir refill. Journal of Water Resources Planning and Management. Vol. 142. Iss. 11 [04016051] p. 1-13.

WoJAS W., TYSZEWSKI S. 2013. Some examples comparing static and dynamic network approaches in water resources allocation models for the rivers of high instability of flows. Journal Water and Land Development. No. 18 p. $21-27$.

WurB R.A. 1996. Modeling and analysis of reservoir system operations. New Jersey. Prentice Hall. ISBN 0136059244 pp. 356. 
Widandi SOETOPO, SUHARDJONO, UsSy ANDAWAYANTI, Rini Wahyu SAYEKTI, Janu ISMOYO

Badanie porównawcze modeli zrzutu wody ze zbiornika do nawadniania, przykład zbiornika Sutami

\section{STRESZCZENIE}

W pracy omówiono trzy modele zasad eksploatacji dużego zbiornika, którego wody są wykorzystywane do nawodnień. Są to: zasada pięćdziesięcioelementowej ciągłej linii pojemności zbiornika, zasada pojedynczej krzywej i zasada czterech krzywych pojemności zbiornika. Wymienione trzy modele były optymalizowane przez losową symulację z użyciem danych o dopływie z 30 lat z zastosowaniem maksymalizacji wartości średniej rocznej produkcji w nawadnianym obszarze jako funkcji obiektywnej. Celem prezentowanych badań było poszukiwanie odpowiednich zasad eksploatacji zbiornika Sutami. Optymalizację realizowano wstępnie poprzez losowe poszukiwanie stochastycznego modelu symulacji dla uzyskania szeregu alternatywnych rozwiązań. Rozwiązania te ulepszano, stosując model genetycznego algorytmu. Następnie najlepsze rozwiązania sprawdzano, stosując Add-Ins Solver programu MS-Excel 2010, by sprawdzić, czy można je jeszcze usprawnić. Wyniki dowiodły, że model czterech krzywych dawał najlepsze rozwiązania przy rocznej produkcji w nawadnianym obszarze o wartości 72,248 miliona dolarów.

Słowa kluczowe: symulacja stochastyczna, zasada, zbiornik, zrzut wody 